problems of British agriculture. The present volume follows upon the lines of the previous issues as to the seven departments of research covered, and each of these sections is compiled by an acknowledged authority on the subject. The volumes are issued free to members of the Society upon application to the Secretary, 16 Bedford Square, London, W.C.1, and at a nominal charge of $1 s$. $3 d$., including postage, to the general public. The Research Committee, under the direction of which they are prepared, is desirous that the information contained in them should be drawn upon freely by county agricultural advisory officers and by the Press, so that it may receive a wide publicity.

\section{Economic Research in Australia}

THE Journal of the Council for Scientific and Industrial Research of the Commonwealth of Australia contains reports of many investigations of pressing economic problems, to some of which reference will be made under our Research Items. Here we simply wish to congratulate the Council upon the completion of its new Animal Health Laboratory, the result of a sum of $£ 20,000$ given by Mr. F. D. MeMaster for that purpose. The Laboratory is placed within the grounds of the University of Sydney, alongside the buildings of the Veterinary Department, and the closest contact is maintained between the two staffs. The work already in progress in the building relates to internal parasites of sheep, including nutritional aspects of this problem, contagious mammites, certain aspects of foot-rot of sheep, and other problems. It is obvious that the Laboratory is in a position to play an important part in the study of those aspects of the Australian pastoral industry which are in great need of solution if the industry is to flourish. The building is of brick, with red-tiled roof, measures 155 feet by 43 feet, is two-storied, and has been constructed so that other stories or rooms may be added with the minimum of disturbance.

\section{New Chief Entomologist at Rothamsted}

THE position of Chief Entomologist at the Rothamsted Experimental Station, rendered vacant by the appointment of Dr. A. D. Imms as head of the new Department of Entomology at Cambridge, is to be filled by Dr. C. B. Williams, lecturer in agricultural and forest zoology, University of Edinburgh. Dr. Williams has had a distinguished career as entomologist in various parts of the British Empire; he received his training at Cambridge and then at the John Innes Horticultural Institution, Merton. After a period of travel in Canada and the United States, he was appointed to the Department of Agriculture of Trinidad, in charge of froghopper investigations, where he stayed for five years. He then became subdirector and afterwards director of the Entomological Section, Ministry of Agriculture, Egypt, and after six years' service was appointed entomologist to the East African Agricultural Research Station, Amani, Tanganyika. He is shortly proceeding to the United States of America to give a course of lectures at the Agricultural Department of the University of Minnesota, and will take up his duties at the Rothamsted Experimental Station on July 1.

\section{Fellowship of African Research}

$I_{T}$ is announced that a Rockefeller fellowship for research work in Africa has been awarded to Miss L. C. Mair. Miss Mair has worked with Prof. B. Malinowski at the London School of Economics as research assistant. She has already left for Uganda, where she will study native social institutions with special reference to the changes which have been brought about by European settlement. The comparatively highly organised character of the social institutions of the Baganda before they came into contact with Europeans, and the readiness the people have shown in adapting themselves in certain directions to European ideas, should make this a fruitful and particularly instructive field of inquiry, especially if opportunity should arise for comparison with other areas of East Africa in which contact with European civilisation has been neither so prolonged nor so intense.

\section{The Cuba Earthquake of Feb. 3}

According to the Wire Reports for Feb. 3 and 4 issued by Science Service, the epicentre of the Cuba earthquake of Feb. 3 lay in about lat. $19.5^{\circ} \mathrm{N}$., long. $76.5^{\circ} \mathrm{W}$., or about thirty miles from Santiago, on the northern edge of the Bartlett Deep. At the time of the earthquake, Prof. S. Taber was in Santiago, studying the seismology of the district. He has found faults near Santiago so fresh that gullies made by rain have not yet crossed them. The U.S. submarine $S-48$, carrying an international scientific expedition, left on Feb. 4 to study the depths and changes of depth in the Bartlett Deep, an inquiry that may add to our knowledge of the origin of the recent earthquake.

\section{Announcements}

The thirty-seventh annual congress of the SouthEastern Union of Scientific Societies will be held in London, at the Civil Service Commission, Burlington House, W.1, by permission of H.M. Office of Works, on June 1-4, under the presidency of Dr. R. E. Mortimer Wheeler, Keeper of the London Museum.

ON March 7, the Hon. Henry McLaren, president of the Royal Horticultural Society, will unveil a plaque at Messrs. Hatchards, 187 Piccadilly, London, to commemorate the foundation of the Horticultural Society of London at Messrs. Hatchards on March 7, 1804. The Society received its royal charter on April 7, 1809, becoming the Royal Horticultural Society.

AT the annual general meeting of the Quekett Microscopical Club, held on Feb. 9, the following officers and new members of the committee were elected : President-J. Milton Offord; Vice-Presidents-Dr. G. H. Rodman, J. Wilson, C. D. Soar, and J. Ramsbottom; Hon. Treasurer-C. H. Bestow; Hon. Secretary-W. S. Warton; Hon. ReporterA. Morley Jones; Hon. Librarian-C. H. Caffyn ; Hon. Curator-C. D. Sidwell ; Hon. Editor-W. S. Warton; New Members of Committee-J. T. Holder, C. H. Oakden, H. C. Payne, J. Richardson, W. P. Sollas, and Dr. C. Tierney. 